\title{
Transfer of Erwinia ananas (synonym, Erwinia uredovora) and Erwinia stewartii to the Genus Pantoea emend. as Pantoea ananas (Serrano 1928) comb. nov. and Pantoea stewartii (Smith 1898) comb. nov., Respectively, and Description of Pantoea stewartii subsp. indologenes subsp. nov.
}

\author{
JORIS MERGAERT, ${ }^{*}$ LINDA VERDONCK, AND KAREL KERSTERS \\ Laboratorium voor Microbiologie, Universiteit Gent, K.L. Ledeganckstraat 35, B-9000 Ghent, Belgium
}

\begin{abstract}
Eight Erwinia stewartii strains, 11 Erwinia ananas strains, and 7 Erwinia uredovora strains, as well as 9 phenotypically similar Erwinia herbicola strains and Enterobacter agglomerans LMG 5342, were compared by examining electropherograms prepared from their soluble proteins and were grouped into nine protein electrophoretic groups. The levels of DNA relatedness among these electrophoretic groups were determined spectrophotometrically from the renaturation rates at $74^{\circ} \mathrm{C}$ of the DNAs of 13 selected strains. The representatives from five protein electrophoretic groups, including $E$. ananas $L M G 2665^{\mathrm{T}}$ ( $T=$ type strain) and E. uredovora LMG 2667 $7^{\mathrm{T}}$, exhibited 76 to $100 \%$ DNA binding to each other and constituted DNA hybridization group 2665. All $E$. stewartii strains (including LMG $2715^{\mathrm{T}}$ ) were electrophoretically very similar; representatives of this species exhibited 93 to $99 \%$ DNA binding to each other and constituted DNA hybridization subgroup 2715. The strains belonging to the remaining three protein electrophoretic groups exhibited 94 to 96\% DNA binding to each other and formed DNA hybridization subgroup 2632. The latter two subgroups were 60 to $83 \%$ (average, $73 \%$ ) interrelated and exhibited 30 to $39 \%$ DNA binding to group 2665 . It is proposed that $E$. ananas and $E$. uredovora should be united in a single species, which should be classified in the genus Pantoea as Pantoea ananas (Serrano 1928) comb. nov.; its type strain is strain LMG 2665 (= NCPPB 1846). This species also includes DNA hybridization group VI of Brenner et al. (D. J. Brenner, G. R. Fanning, J. K. Leete Knutson, A. G. Steigerwalt, and M. I. Krichevsky, Int. J. Syst. Bacteriol. 34:45-55, 1984). The transfer of $E$. stewartii to the genus Pantoea and the creation of two separate subspecies within Pantoea stewartii (Smith 1898) comb. nov. are also proposed. Pantoea stewartii subsp. stewartii (Smith 1898) comb. nov. (synonym, Erwinia stewartii) contains the strains belonging to subgroup 2715, and its type strain is strain LMG 2715 (= NCPPB 2295); and Pantoea stewartii subsp. indologenes subsp. nov. contains the strains belonging to subgroup 2632, and its type strain is strain LMG 2632 (= NCPPB 2280). As determined by principal-component analysis of the cellular fatty acid compositions, $P$. ananas, $P$. stewartii subsp. stewartii, and $P$. stewartii subsp. indologenes are separated from each other mainly by differences in the relative contents of cis-9-hexadecenoic acid ( $\left.C_{16: 1 \text { cis }}\right)$, cyclo-heptadecanoic acid $\left(\mathbf{C}_{17: 0}\right.$ cyclo $)$, and straight-chain octodecenoic acids $\left(\mathbf{C}_{\text {18:1 }}\right)$. P. stewartii subsp. stewartii can also be differentiated from $P$. ananas and $P$. stewartii subsp. indologenes by its inability to produce indole, to utilize citrate, to grow on cis-aconitate, and to form acid from seven carbohydrates. $P$. stewartii subsp. indologenes can also be separated from $P$. ananas by its inability to form acid from sorbitol and $\alpha$-methyl-Dmannoside. Descriptions of $P$. ananas and $P$. stewartii and its two subspecies are given, and the description of the genus Pantoea is emended.
\end{abstract}

In 1972 Ewing and Fife (16) proposed the name Enterobacter agglomerans to accomodate the "herbicola group" (13) of the genus Erwinia. This taxon included the species Erwinia herbicola, Enwinia milletiae, Erwinia ananas, Erwinia uredovora, and (according to Brenner [6] and Richard [39]) Erwinia stewartii, as well as Escherichia adecarboxylata and other phenotypically similar strains of clinical origin. Many authors demonstrated the extreme heterogeneity of the "Erwinia herbicola-Enterobacter agglomerans" complex on phenotypic $(18,32-34,45)$ as well as genotypic levels $(5,7,19,26,29)$. Some of the members of this complex were placed in new genera. Escherichia adecarboxylata was renamed Leclercia adecarboxylata (44), despite its affinities with Enterobacter cloacae and Enterobacter amnigenus (26). Subjective synonymy of the species names Enterobacter agglomerans, Erwinia herbicola, and Enwinia milletiae was suspected on phenotypic grounds $(18,34,45)$ and was

\footnotetext{
${ }^{*}$ Corresponding author.
}

confirmed by the high levels (>90\%) of DNA binding observed $(5,29)$ and the similarity of the electrophoretic protein patterns of the type strains of these species (33). It was proposed (19) that a new genus Pantoea should be established, with type species Pantoea agglomerans, to include the type strains of Enterobacter agglomerans, Erwinia herbicola, and Erwinia milletiae, as well as the other strains belonging to electrophoretic protein profile groups I and III to VI of Beji et al. (5) and DNA hybridization group XIII of Brenner et al. (7). Gavini et al. (19) proposed the name Pantoea dispersa for the strains of their DNA hybridization group 14589, in which they included DNA hybridization group III of Brenner et al. (7). These authors suggested that other members of the "Enwinia herbicola-Enterobacter agglomerans" complex might also be included in the genus Pantoea, but lacked comparative data for a sufficient number of strains to do so. More recently, three new species isolated from fruits and soils were described and classified in the genus Pantoea on the basis of phenotypic and chemo- 
systematic characteristics (Pantoea punctata, Pantoea citrea, and Pantoea terrea) (27).

Synonymy of the names Erwinia ananas and Erwinia uredovora has been suspected $(14,34,45)$ on phenotypic grounds, but has not yet been confirmed by DNA hybridization data. In the numerical analysis of Verdonck et al. (45), Erwinia uredovora and Erwinia ananas strains were mixed up with several (obviously misnamed) Erwinia herbicola strains and Enterobacter agglomerans CDC 6076-69 (= LMG 5342), a reference strain of DNA hybridization group VI of Brenner et al. (7). In this paper, we describe the interand intraspecific relationships of Enwinia ananas, Erwinia uredovora, and Erwinia stewartii strains and other phenotypically similar strains. On the basis of our data and data from previous papers $(5,7,19,29)$, we propose the new combinations Pantoea ananas (synonyms, Erwinia ananas and Erwinia uredovora) and Pantoea stewartii and describe a new subspecies, Pantoea stewartii subsp. indologenes.

\section{MATERIALS AND METHODS}

Strains used. The 36 strains used in this study are listed in Table 1. For comparison, Pantoea agglomerans LMG $1286^{\mathrm{T}}$ (= NCTC $9381^{\mathrm{T}}=$ ATCC $\left.27155^{\mathrm{T}}\right)(\mathrm{T}=$ type strain $)$ and LMG 2565 (= NCPPB 2971), Pantoea dispersa LMG 2603 ${ }^{\mathrm{T}}$ $\left(=\right.$ ATCC $\left.14589^{\mathrm{T}}\right)$ and LMG 2749 (= Lille 214-6) $(5,19)$, and Enwinia amylovora LMG $2024^{\mathrm{T}}\left(=\right.$ NCPPB $\left.683^{\mathrm{T}}\right)$ were included in some of the experiments.

Polyacrylamide gel electrophoresis of soluble proteins. Protein electropherograms were prepared as described previously (33).

DNA base composition. Mean guanine-plus-cytosine $(\mathrm{G}+\mathrm{C})$ contents were determined by the thermal denaturation method $(10,31)$.

DNA-DNA hybridizations. To prepare DNA, cells were grown at $28^{\circ} \mathrm{C}$ for $48 \mathrm{~h}$ in Roux flasks on a medium containing $1 \%$ tryptone (Oxoid), $1 \%$ proteose peptone (Oxoid), $0.15 \%$ $\mathrm{K}_{2} \mathrm{HPO}_{4}, 0.3 \% \mathrm{MgSO}_{4} \cdot 7 \mathrm{H}_{2} \mathrm{O}, 1.0 \%$ glycerol, and $2.5 \%$ agar in distilled water. DNA was prepared by the method of Marmur (30). Percentages of DNA binding were determined spectrophotometrically from renaturation rates by the method of De Ley et al. (11). The optimal renaturation temperature, calculated from the $G+C$ content with the equation of De Ley et al. (11), was approximately $74^{\circ} \mathrm{C}$ in double-strength standard saline citrate buffer.

Phenotypic tests. Tests in API 20E and API 50CHE systems (bioMérieux, La Balme les Grottes, Montalieu Vercieu, France) were performed at $30^{\circ} \mathrm{C}$ by the procedures described previously (34). API $20 \mathrm{E}$ results were coded and interpreted with the APILAB V3.1.1 computer program. The following characteristics were also tested: motility; pigment production on nutrient agar medium (Oxoid); gas production from glucose (in a $1 \%$ peptone-water solution supplemented with $1 \% \mathrm{D}$-glucose); phenylalanine deaminase activity; acid production on Jordan's tartrate medium; utilization of malonate and mucate (15); growth at different temperatures (in a medium containing $0.5 \%$ yeast extract, $0.5 \%$ neutralized peptone, and $1 \% \mathrm{D}$-glucose); tetrathionate reductase activity (28); DNase activity (on Oxoid medium supplemented with $0.01 \%$ toluidine blue); hydrolysis of Tween 20, Tween 40, Tween 60, and Tween 80 (41); pectate degradation (37); and growth on medium containing acetate, cis-aconitate, DL-4-aminobutyrate, DL-3-hydroxybutyrate, meso-tartrate, or D-malate (tested on the medium of Ayers et al. [3], which contained $0.25 \% \mathrm{MgSO}_{4} \cdot 7 \mathrm{H}_{2} \mathrm{O}, 0.25 \% \mathrm{KCl}$,
$0.125 \% \mathrm{NH}_{4} \mathrm{H}_{2} \mathrm{PO}_{4}, 0.5 \%$ carbon source substrate, and $2 \%$ agar).

Fatty acid analyses. A quantitative analysis of cellular fatty acid compositions was performed by using the gas-liquid chromatographic procedure described by Alcorn et al. (2), with the modifications described below. Fatty acid methyl esters were extracted with a mixture of hexane and methyliso-butylether. Fatty acid methyl esters were analyzed with a Hewlett-Packard model 5890A gas chromatograph and were identified by using the Microbial Identification System (MIS) software (version 3.5) (Microbial ID, Inc., Newark, Del.). A principal-component analysis was carried out by using the same software package.

\section{RESULTS}

Comparison of protein electropherograms. Protein electropherograms were prepared for the 36 strains listed in Table 1 and for Pantoea agglomerans LMG $1286^{\mathrm{T}}$ and Pantoea dispersa LMG $2603^{\mathrm{T}}$ and were compared by visually inspecting the normalized photographs. Among the strains listed in Table 1, nine protein profile groups, each of which had a characteristic protein profile, could be recognized (Fig. 1 and 2). These groups contained strains with similar protein patterns. In some groups variations in the intensities of the protein bands in the upper part of the gel (e.g., protein profile group II) or the lower part of the gel (protein profile group VIII) were obvious, while in other groups the protein patterns were almost identical (protein profile group I).

Protein profile groups I and II each contained four strains of Erwinia ananas. Protein profile group II included type strain LMG 2665, as well as Enwinia herbicola LMG 2101. Protein profile groups III and IV each contained three Erwinia uredovora strains; protein profile group IV included type strain LMG 2676. Enterobacter agglomerans LMG 5342 (= CDC 6070-69; a reference strain belonging to DNA hybridization group VI of Brenner et al. [7]), Erwinia herbicola LMG 2628, and Erwinia uredovora LMG 2679 constituted protein profile group $\mathrm{V}$ (Fig. 1).

Protein profile groups VI and VIII contained three and four Erwinia herbicola strains, respectively. Protein profile group VII consisted of three Erwinia ananas strains. Finally, all Erwinia stewartii strains, including type strain LMG 2715, were electrophoretically similar and constituted protein profile group IX (Fig. 2).

The electrophoretic protein profiles of groups I to IX were significantly different from those of Pantoea agglomerans LMG $1268^{\mathrm{T}}$ and Pantoea dispersa LMG $2603^{\mathrm{T}}$ (Fig. 1 and 2).

DNA base compositions. The DNA base compositions of four strains were determined in duplicate. The differences between the duplicate test results were less than $0.5 \mathrm{~mol} \%$ in each case. The $\mathrm{G}+\mathrm{C}$ contents of the DNAs of Erwinia ananas LMG $2665^{\mathrm{T}}$ and LMG 2673 and Erwinia herbicola LMG 2630 and LMG 2632 were 55.0, 54.5, 54.7, and 56.4 mol\%, respectively.

DNA-DNA hybridizations. In order to determine the genotypic relationships among the different electrophoretic protein profile groups, 13 representative strains were selected for DNA-DNA hybridization experiments. Representative strains of Pantoea agglomerans and Pantoea dispersa were included for comparison. The results are shown as a sorted matrix of percentages of DNA binding in Fig. 3; the percentages are averages of two to four determinations. Among the strains belonging to protein profile groups I to VII two major DNA hybridization groups could be distinguished.

DNA hybridization group 2665 contained all seven strains 
TABLE 1. Strains used, their sources, and their API 20E profile numbers

\begin{tabular}{|c|c|c|c|c|c|c|}
\hline Group & $\begin{array}{l}\text { Species name } \\
\text { as received }\end{array}$ & Strain $^{a}$ & $\begin{array}{l}\text { Strain designation } \\
\text { as received } \\
\end{array}$ & Isolated in: & Isolated from: & $\begin{array}{l}\text { API } 20 \mathrm{E} \\
\text { profile }^{b}\end{array}$ \\
\hline \multicolumn{7}{|c|}{$\begin{array}{l}\text { Pantoea ananas (Serrano 1928) } \\
\text { comb. nov. }\end{array}$} \\
\hline \multirow[t]{4}{*}{ Protein profile group I } & Erwinia ananas & LMG 2666 & Graham BGl & Hawaii & Ananas comosus & 1245773 \\
\hline & Erwinia ananas & LMG 2667 & Graham BG2 & Hawaii & Ananas comosus & 1245773 \\
\hline & Envinia ananas & LMG 2668 & Graham MF28 & Hawaii & Ananas comosus & 1245563 \\
\hline & Erwinia ananas & LMG 2669 & Graham Y1 & Hawaii & Ananas comosus & 1245563 \\
\hline \multirow[t]{5}{*}{ Protein profile group II } & Erwinia herbicola & LMG 2101 & Graham G144 & India & Onyza sativa & 1245163 \\
\hline & Erwinia ananas & LMG 2664 & NCPPB 544 & Hawaii & Ananas comosus & 1245773 \\
\hline & Erwinia ananas & LMG $2665^{\mathrm{T} c, d}$ & NCPPB $1846^{\mathrm{T} c, d}$ & Brazil & Ananas comosus & 1245573 \\
\hline & Enwinia ananas & LMG 2670 & NCPPB 545 & Hawaii & Ananas comosus & 1245373 \\
\hline & Enwinia ananas & LMG 2672 & HIM 597-3 & & Ananas comosus & 1245573 \\
\hline \multirow[t]{3}{*}{ Protein profile group III } & Erwinia uredovora & LMG 2675 & NCPPB 391 & Hungary & $\begin{array}{l}\text { Puccinia graminis f. } \\
\text { sp. tritici }\end{array}$ & 1245773 \\
\hline & Erwinia uredovora & LMG 2677 & NCPPB 802 & Hungary & $\begin{array}{l}\text { Puccinia graminis } \mathrm{f} . \\
\text { sp. tritici }\end{array}$ & 1247773 \\
\hline & Erwinia uredovora & LMG 2681 & NCPPB 1440 & Hungary & $\begin{array}{l}\text { Puccinia graminis f. } \\
\quad \text { sp. tritici }\end{array}$ & 1247773 \\
\hline \multirow[t]{3}{*}{ Protein profile group IV } & Enwinia uredovora & LMG $2676^{\text {Td }}$ & NCPPB $800^{\mathrm{T} d}$ & United States & $\begin{array}{l}\text { Puccinia graminis f. } \\
\quad \text { sp. tritici }\end{array}$ & 1247573 \\
\hline & Erwinia uredovora & LMG 2678 & NCPPB 1044 & Zimbabwe & $\begin{array}{l}\text { Puccinia graminis f. } \\
\text { sp. tritici }\end{array}$ & 1244773 \\
\hline & Erwinia uredovora & LMG 2680 & NCPPB 1419 & Hungary & $\begin{array}{l}\text { Puccinia graminis f. } \\
\quad \text { sp. tritici }\end{array}$ & 1244773 \\
\hline \multirow[t]{3}{*}{ Protein profile group $\mathrm{V}$} & Erwinia herbicola & LMG 2628 & HIM $577-8$ & & Musa sp. & 1244773 \\
\hline & Erwinia uredovora & LMG 2679 & NCPPB 1416 & Hungary & $\begin{array}{l}\text { Puccinia graminis f. } \\
\quad \text { sp. tritici }\end{array}$ & 1245773 \\
\hline & $\begin{array}{l}\text { Enterobacter ag- } \\
\text { glomerans }\end{array}$ & LMG 5342 & CDC $6070-69$ & United States & $\begin{array}{l}\text { Human clinical } \\
\text { isolate }\end{array}$ & 1245773 \\
\hline \multicolumn{7}{|l|}{$\begin{array}{c}\text { Pantoea stewartii subsp. in- } \\
\text { dologenes subsp. nov. }\end{array}$} \\
\hline \multirow[t]{3}{*}{ Protein profile group VI } & Erwinia herbicola & LMG 2630 & NCPPB 1877 & & $\begin{array}{l}\text { Cyamopsis } \\
\text { tetragonolobus }\end{array}$ & 1045163 \\
\hline & Erwinia herbicola & LMG 2631 & NCPPB 2275 & India & $\begin{array}{l}\text { Pennisetum } \\
\text { americanum }\end{array}$ & 1245163 \\
\hline & Erwinia herbicola & LMG 2635 & NCPPB 2283 & India & $\begin{array}{l}\text { Pennisetum } \\
\text { americanum }\end{array}$ & 1245163 \\
\hline \multirow[t]{3}{*}{ Protein profile group VII } & Enwinia ananas & LMG 2671 & NCPPB 1845 & Hawaii & Ananas comosus & 1245163 \\
\hline & Erwinia ananas & LMG 2673 & PDDCC 1517 & Hawaii & Ananas comosus & 1245163 \\
\hline & Erwinia ananas & LMG 2674 & PDDCC 1518 & Hawaii & Ananas comosus & 1245163 \\
\hline \multirow[t]{4}{*}{ Protein profile group VIII } & Erwinia herbicola & LMG 2629 & NCPPB 1562 & India & $\begin{array}{l}\text { Pennisetum } \\
\text { americanum }\end{array}$ & 1244163 \\
\hline & Enwinia herbicola & LMG $2632^{\mathrm{T} c}$ & NCPPB $2280^{\mathrm{T} c}$ & India & Setaria italica & 1245163 \\
\hline & Erwinia herbicola & LMG 2633 & NCPPB 2281 & India & Setaria italica & 1244163 \\
\hline & Enwinia herbicola & LMG 2634 & NCPPB 2282 & India & $\begin{array}{l}\text { Pennisetum } \\
\text { americanum }\end{array}$ & 1245163 \\
\hline \multicolumn{7}{|l|}{$\begin{array}{l}\text { Pantoea stewartii subsp. stew- } \\
\text { artii (Smith 1898) comb. } \\
\text { nov. }\end{array}$} \\
\hline \multirow[t]{8}{*}{ Protein profile group IX } & Erwinia stewartii & LMG 2712 & NCPPB 449 & United States & $\begin{array}{l}\text { Zea mays var. } \\
\text { rugosa }\end{array}$ & 1004162 \\
\hline & Erwinia stewartii & LMG 2713 & NCPPB 1553 & United States & Zea mays & 1004162 \\
\hline & Enwinia stewartii & LMG 2714 & NCPPB 2294 & United States & Zea mays & 1005162 \\
\hline & Erwinia stewartii & LMG $2715^{\text {Tc,d }}$ & NCPPB $2295^{\mathrm{T} c, d}$ & United States & $\begin{array}{l}\text { Zea mays var. } \\
\text { rugosa }\end{array}$ & 1004162 \\
\hline & Enwinia stewartii & LMB 2716 & PDDCC 270 & United States & $\begin{array}{l}\text { Zea mays var. } \\
\text { rugosa }\end{array}$ & 1004162 \\
\hline & Erwinia stewartii & LMG 2717 & PDDCC 722 & United States & Beetle & 1005162 \\
\hline & Enwinia stewartii & LMG 2718 & PDDCC 724 & United States & & 1004162 \\
\hline & Erwinia stewartii & LMG 2719 & PDDCC 5929 & United States & Corn flea beetle & 1004162 \\
\hline
\end{tabular}

a Abbreviations: CDC, Centers for Disease Control, Atlanta, Ga.; Graham, D. C. Graham, Department of Agriculture and Fisheries for Scotland, Agricultural Scientific Services, Edinburgh, Scotland; HIM, Hygiene-Institut und Medizinal-Untersuchungsamt, University of Marburg, Marburg/Lahn, Germany; LMG, Culture Collection, Laboratorium voor Microbiologie, Ghent, Belgium; NCPPB, National Collection of Plant Pathogenic Bacteria, Harpenden, England; PDDCC, Plant Diseases Division Culture Collection, Auckland, New Zealand.

${ }^{b}$ After $24 \mathrm{~h}$ of incubation at $30^{\circ} \mathrm{C}$.

$c$ Type strain of proposed Pantoea species or subspecies.

${ }^{d}$ Type strain of Erwinia species (42). 


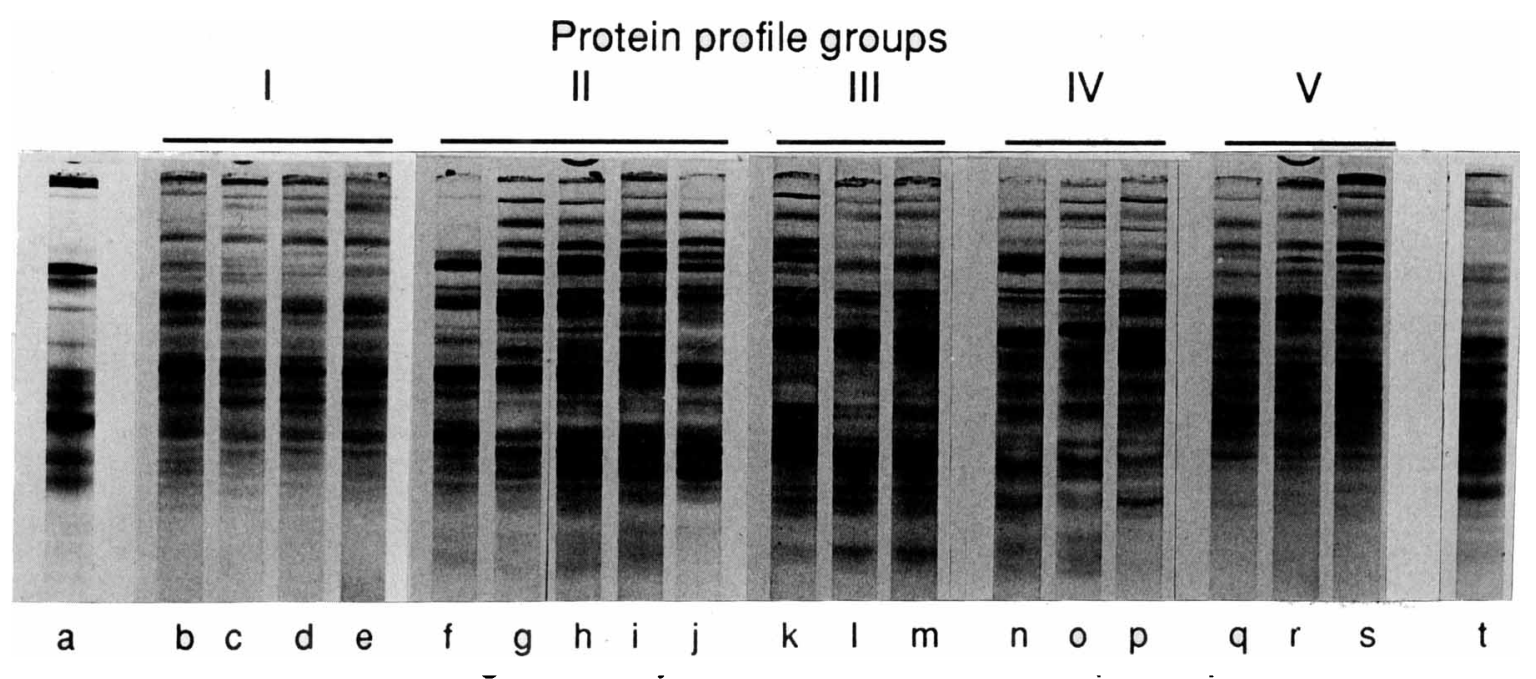

FIG. 1. Normalized protein electropherograms for 18 strains of Pantoea ananas and the type strains of Pantoea agglomerans and Pantoea dispersa. Lane a, Pantoea agglomerans LMG 1286 ${ }^{\mathrm{T}}$; lanes b through s, Pantoea ananas LMG 2666, LMG 2667, LMG 2668, LMG 2669, LMG

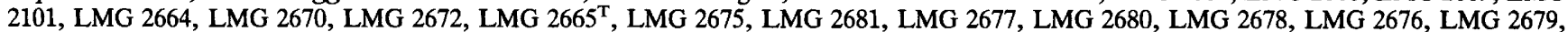
LMG 2628, and LMG 5342, respectively; lane t, Pantoea dispersa LMG $2603^{\mathrm{T}}$.

belonging to protein profile groups I to $\mathrm{V}$ tested. It included type strains Erwinia uredovora LMG 2676 and Erwinia ananas LMG 2665. Strains belonging to this DNA hybridization group exhibited 76 to $100 \%$ DNA binding to each other. The levels of interspecies DNA binding of the Erwinia uredovora and Enwinia ananas strains in this group were as high as $99 \%$, and the level of DNA binding was $79 \%$ when the DNAs of the type strains were hybridized.

The second DNA hybridization group contained the reference strains of protein profile groups VI to IX. Within this DNA hybridization group two genomic subgroups could be recognized, each consisting of three strains which exhibited more than $93 \%$ DNA binding to each other. The levels of DNA binding calculated between members of the two subgroups ranged from 60 to $83 \%$. Subgroup 2632 contained the strains belonging to protein profile groups VI to VIII, and subgroup 2715 contained the strains of Erwinia stewartii tested (protein profile group IX), including type strain LMG 2715.

Representatives of DNA hybridization group 2665 exhibited 30 to $32 \%$ DNA binding to Erwinia stewartii LMG $2715^{\mathrm{T}}$, a member of DNA hybridization subgroup 2715 , and 32 to $39 \%$ DNA binding to strains belonging to DNA hybridization subgroup 2632.

Strains of Pantoea agglomerans and Pantoea dispersa exhibited 18 to $34 \%$ DNA binding to members of DNA hybridization group 2665 and DNA hybridization subgroups 2715 and 2632 .

Phenotypic features. The results of the phenotypic tests are shown in Table 2.

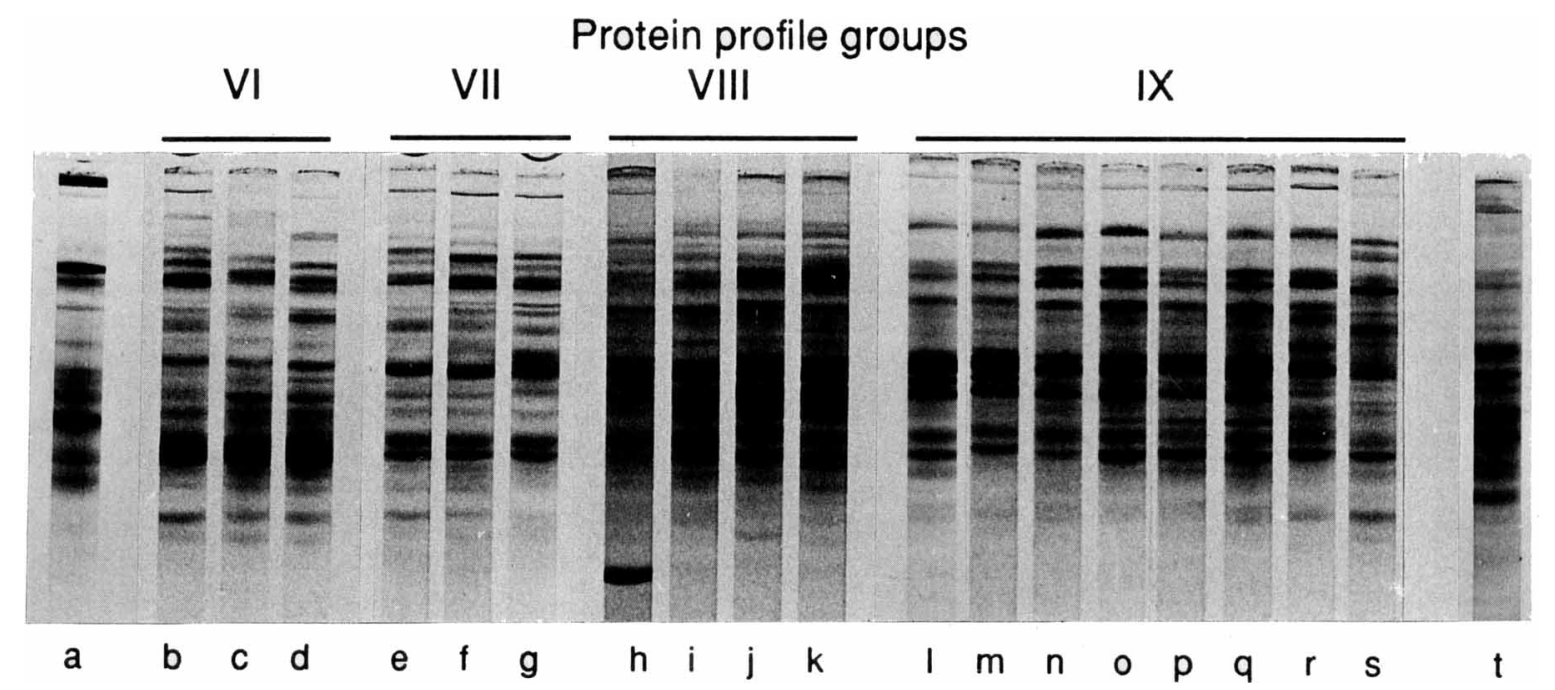

FIG. 2. Normalized protein electropherograms for 18 strains of Pantoea stewartii and the type strains of Pantoea agglomerans and Pantoea dispersa. Lane a, Pantoea agglomerans LMG $1286^{\mathrm{T}}$; lanes b through k, Pantoea stewartii subsp. indologenes LMG 2631, LMG 2635, LMG 2630, LMG 2673, LMG 2674, LMG 2671, LMG 2629, LMG 2634, LMG 2632 , and LMG 2633, respectively; lanes 1 through s, Pantoea stewartii subsp. stewartii LMG 2715 ${ }^{\mathrm{T}}$, LMG 2717, LMG 2714, LMG 2712, LMG 2719, LMG 2713, LMG 2716, and LMG 2718, respectively; lane t, Pantoea dispersa LMG $2603^{\mathrm{T}}$. 


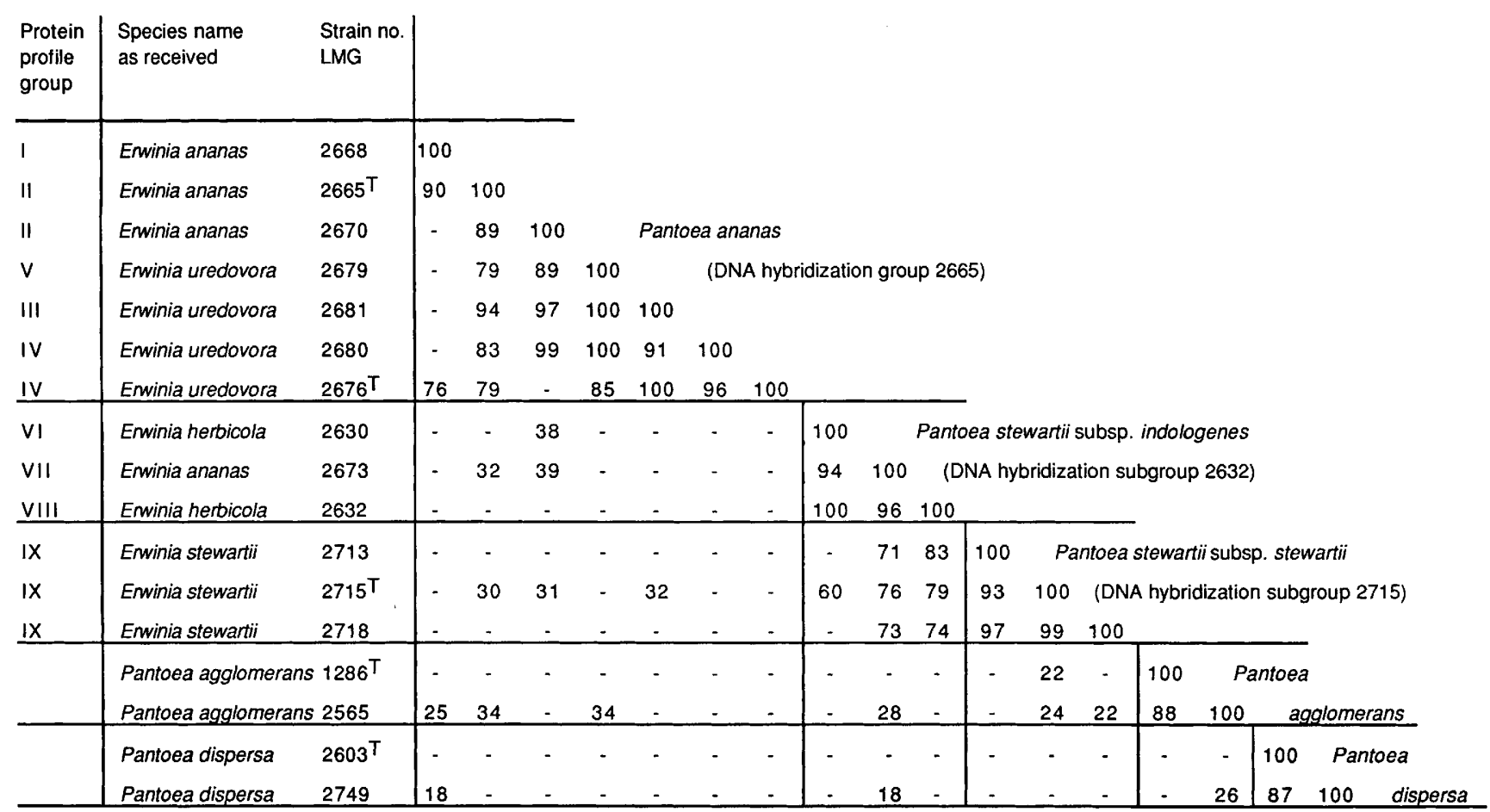

FIG. 3. Sorted matrix of average percentages of DNA binding for 17 Pantoea strains. The percentages obtained from homologous reactions were, by definition, set at 100\%. Strains LMG 2665, LMG 2632, and LMG 2715 are type strains of the proposed Pantoea species and subspecies.

API 20E seven-digit codes. The strains belonging to protein profile groups I to IX were tested in the API $20 \mathrm{E}$ system, and the seven-digit codes obtained are shown in Table 1 . These codes did not correlate with the electrophoretic groups.

The eight different codes obtained for protein profile groups I to V (DNA hybridization group 2665) were correctly identified as Erwinia ananas or Erwinia uredovora codes by the APILAB profile recognition program. Both codes obtained for the Erwinia stewartii strains were identified as Erwinia mallotivora codes. The three codes obtained for the strains belonging to protein profile groups VI to VIII (DNA hybridization subgroup 2632) were identified as Erwinia ananas or Erwinia uredovora codes. In most cases reactions in additional tests (yellow pigment; gas production from D-glucose; esculin hydrolysis; acid production from $\alpha$-methyl-D-glucoside, lactose, D-xylose, and trehalose) had to be used to differentiate the strains used in this study from Enterobacter agglomerans, Klebsiella oxytoca, Serratia plymuthica, and other Erwinia species.

Fatty acid analyses. The relative cellular fatty acid compositions of all of the strains were determined and are shown in Table 3. The groups defined by DNA hybridization characteristics and the type strains of Pantoea agglomerans, Pantoea dispersa, and Erwinia amylovora were separated in the principal-component analysis by using principal components 1 and 2 (Fig. 4). The separation of these groups and type strains was based mainly on differences in relative contents of cis-9-hexadecenoic acid $\left(\mathrm{C}_{16: 1 \text { cis } 9}\right)$, cyclo-heptadecanoic acid $\left(\mathrm{C}_{17: 0 \text { cyclo }}\right)$, and straight-chain octodecenoic acids $\left(\mathrm{C}_{18: 1}\right)$ (Table 3 , summed feature 7 ). DNA hybridization group 2665 and DNA hybridization subgroup 2632 exhibited greater similarity in their fatty acid methyl ester compositions to each other than to DNA hybridization subgroup 2715. Erwinia ananas strains belonging to protein profile groups I and II intermingled with the Erwinia uredovora strains in the analysis. The standard MIS library (version 3.5) identified the strains belonging to protein profile groups I to V (DNA hybridization group 2665) as Erwinia uredovora, with the genus Cedecea as the second choice, or vice versa. All of the Erwinia stewartii strains were identified as such. For the strains belonging to protein profile groups VI to VIII (DNA hybridization subgroup 2632) the MIS program gave low identification scores $(<0.4)$ and could not differentiate among the genus Cedecea, Enterobacter cloacae, Citrobacter diversus, and Erwinia uredovora.

\section{DISCUSSION}

Seven strains received as Erwinia ananas and Erwinia uredovora (including their type strains [strains LMG 2665 and LMG 2676, respectively]) exhibited 76 to $100 \%$ DNA binding to each other and constituted DNA hybridization group 2665 (Fig. 3). The existence of five different electrophoretic groups within this DNA hybridization group (Fig. 1) indicates that the taxonomic resolution of the electrophoretic technique which we used is at an intraspecific level. The high levels of DNA binding observed between strains which produced similar or identical protein patterns $(89,96$, and 93 to $99 \%$ within protein profile groups II, IV, and IX, respectively [Fig. 3]) are in accordance with previous observations $(5,19,26)$. Consequently, we assign all of the strains belonging to protein profile groups I to V to DNA hybridization group 2665. Five strains belonging to these protein profile groups (strains LMG 2668 [= ICPB EA181], LMG 2628 [= ATCC 23822], LMG 2676 [= ICPB XU102], LMG 2677 [= ICPB XU104], and LMG 5342) were classified in DNA hybridization group VI by Brenner et al. (7). Therefore, we concluded that DNA hybridization group VI of 
TABLE 2. Phenotypic characteristics of Pantoea ananas (DNA hybridization group 2665), Pantoea stewartii subsp. stewartii (DNA hybridization subgroup 2715), and Pantoea stewartii subsp. indologenes (DNA hybridization subgroup 2632)

\begin{tabular}{|c|c|c|c|c|c|c|}
\hline \multirow[b]{2}{*}{ Characteristic $^{a}$} & \multicolumn{2}{|c|}{ Pantoea ananas } & \multicolumn{2}{|c|}{ Pantoea stewartii subsp. stewartii } & \multicolumn{2}{|c|}{$\begin{array}{l}\text { Pantoea stewartii subsp. } \\
\text { indologenes }\end{array}$} \\
\hline & $\begin{array}{l}\text { No. of strains } \\
\text { positive/no. } \\
\text { of strains } \\
\text { tested }\end{array}$ & $\begin{array}{l}\text { Reaction of type } \\
\text { strain LMG } \\
2665\end{array}$ & $\begin{array}{l}\text { No. of strains } \\
\text { positive/no. } \\
\text { of strains } \\
\text { tested }\end{array}$ & $\begin{array}{l}\text { Reaction of type } \\
\text { strain LMG } \\
2715\end{array}$ & $\begin{array}{l}\text { No. of strains } \\
\text { positive/no. } \\
\text { of strains } \\
\text { tested }\end{array}$ & $\begin{array}{l}\text { Reaction of type } \\
\text { strain LMG } \\
2632\end{array}$ \\
\hline Production of yellow pigment & $17 / 18$ & + & $8 / 8$ & + & $9 / 10$ & + \\
\hline \multicolumn{7}{|l|}{ Growth at: } \\
\hline $4^{\circ} \mathrm{C}$ & $16 / 18$ & + & $2 / 8$ & - & $8 / 10$ & + \\
\hline $37^{\circ} \mathrm{C}$ & $9 / 17$ & - . & $2 / 7$ & - & $7 / 8$ & + \\
\hline $41^{\circ} \mathrm{C}$ & $4 / 17$ & - & $0 / 7$ & - & $3 / 8$ & - \\
\hline $44^{\circ} \mathrm{C}$ & $1 / 17$ & - & $0 / 7$ & - & $2 / 8$ & - \\
\hline Motility & $17 / 18$ & + & $0 / 8$ & - & $8 / 10$ & + \\
\hline Gelatin liquefaction & $4 / 18$ & - & $0 / 8$ & - & $0 / 10$ & - \\
\hline Indole production & $18 / 18$ & + & $0 / 8$ & - & $10 / 10$ & + \\
\hline Acetoin production & $15 / 18$ & + & $2 / 8$ & - & $8 / 10$ & + \\
\hline Nitrate reduced to nitrite & $7 / 18$ & - & $0 / 8$ & - & $0 / 10$ & - \\
\hline Hydrolysis of esculin & $9 / 18$ & + & $0 / 8$ & - & $10 / 10$ & + \\
\hline DNase & $9 / 18$ & - & $2 / 8$ & + & $2 / 10$ & - \\
\hline Citrate utilization & $18 / 18$ & + & $0 / 8$ & - & $9 / 10$ & + \\
\hline Malonate utilization & $1 / 18$ & - & $0 / 8$ & - & $0 / 10$ & - \\
\hline Mucate utilization & $7 / 18$ & - & $0 / 8$ & - & $2 / 10$ & - \\
\hline \multicolumn{7}{|l|}{ Hydrolysis of: } \\
\hline Tween 20 & $18 / 18$ & + & $8 / 8$ & + & $7 / 10$ & + \\
\hline Tween 60 & $18 / 18$ & + & $8 / 8$ & + & $9 / 10$ & + \\
\hline Tween 80 & $7 / 18$ & + & $0 / 8$ & - & $0 / 10$ & - \\
\hline \multicolumn{7}{|l|}{ Growth on: } \\
\hline cis-Aconitate & $18 / 18$ & + & $0 / 8$ & - & $10 / 10$ & + \\
\hline DL-4-Aminobutyrate & $7 / 18$ & + & $0 / 8$ & - & $8 / 10$ & + \\
\hline DL-3-Hydroxybutyrate & $1 / 18$ & + & $0 / 8$ & - & $0 / 10$ & - \\
\hline meso-Tartrate & $17 / 18$ & + & $7 / 8$ & - & $10 / 10$ & + \\
\hline D-Malate & $17 / 18$ & + & $8 / 8$ & + & $10 / 10$ & + \\
\hline \multicolumn{7}{|l|}{ Acid produced from: } \\
\hline D-Mannose & $17 / 18$ & + & $8 / 8$ & + & $10 / 10$ & + \\
\hline L-Rhamnose & $14 / 18$ & + & $0 / 8$ & - & $4 / 10$ & + \\
\hline Cellobiose & $18 / 18$ & + & $0 / 8$ & - & $10 / 10$ & + \\
\hline Maltose & $17 / 18$ & + & $0 / 8$ & - & $10 / 10$ & + \\
\hline Lactose & $17 / 18$ & + & $0 / 8$ & - & $10 / 10$ & + \\
\hline Melibiose & $16 / 18$ & + & $8 / 8$ & + & $10 / 10$ & + \\
\hline Gentiobiose & $10 / 18$ & + & $0 / 8$ & - & $5 / 10$ & + \\
\hline Raffinose & $15 / 18$ & + & $8 / 8$ & + & $10 / 10$ & + \\
\hline$\alpha$-Methyl-D-mannoside & $16 / 18$ & + & $0 / 8$ & - & $0 / 10$ & - \\
\hline$\alpha$-Methyl-D-glucoside & $0 / 18$ & - & $0 / 8$ & - & $1 / 10$ & - \\
\hline Arbutin & $17 / 18$ & + & $0 / 8$ & - & $10 / 10$ & + \\
\hline Salicin & $16 / 18$ & + & $0 / 8$ & - & $10 / 10$ & + \\
\hline Amygdalin & $6 / 18$ & + & $0 / 8$ & - & $3 / 10$ & - \\
\hline Glycerol & $17 / 18$ & + & $0 / 8$ & - & $8 / 10$ & + \\
\hline D-Arabitol & $18 / 18$ & + & $0 / 8$ & - & $10 / 10$ & + \\
\hline Dulcitol & $0 / 18$ & - & $0 / 8$ & - & $1 / 10$ & - \\
\hline meso-Inositol & $13 / 18$ & + & $0 / 8$ & - & $3 / 10$ & + \\
\hline Sorbitol & $15 / 18$ & + & $0 / 8$ & - & $0 / 10$ & - \\
\hline D-Gluconate & $9 / 18$ & + & $0 / 8$ & - & $3 / 10$ & - \\
\hline 2-Keto-D-gluconate & $3 / 18$ & - & $0 / 8$ & - & $2 / 10$ & - \\
\hline 5-Keto-D-gluconate & $5 / 18$ & + & $0 / 8$ & - & $4 / 10$ & + \\
\hline
\end{tabular}

${ }^{a}$ Acid production data (API 50CHE tests) were recorded after $48 \mathrm{~h}$, API 20E test data (gelatin liquefaction; indole, acetoin, and hydrogen sulfide production; nitrate reduction; arginine dihydrolase; lysine and ornithine decarboxylases; tryptophan deaminase; $\beta$-D-galactosidase; urease; and citrate utilization) were recorded after $24 \mathrm{~h}$, and data for the other tests were recorded after 3 days. Incubation was at $30^{\circ} \mathrm{C}$, unless stated otherwise. All Pantoea ananas and Pantoea stewartii strains were positive in the following tests: $\beta$-D-galactosidase; hydrolysis of Tween 40; growth on L-aspartate; and acid production from L-arabinose, D-ribose, D-xylose, D-galactose, D-glucose, D-fructose, sucrose, trehalose, $N$-acetyl-D-glucosamine, and D-mannitol. They were all negative in the following tests: production of hydrogen sulfide; gas production from D-glucose; arginine dihydrolase; lysine and ornithine decarboxylases; phenylalanine and tryptophan deaminases; tetrathionate reductase; urease; oxidase; Jordan's tartrate; pectate degradation; growth on acetate; and acid production from D-arabinose, L-xylose, D-lyxose, L-sorbose, D-tagatose, D-fucose, L-fucose, D-turanose, melezitose, inulin, starch, glycogen, $\beta$-methyl-D-xyloside, meso-erythritol, adonitol, mesoxylitol, and L-arabitol. 
TABLE 3. Cellular fatty acid compositions of Pantoea ananas (DNA hybridization group 2665), Pantoea stewartii subsp. stewartii

(DNA hybridization subgroup 2715), Pantoea stewartii subsp. indologenes (DNA hybridization subgroup 2632), Pantoea agglomerans LMG $1286^{\mathrm{T}}$, Pantoea dispersa LMG $2603^{\mathrm{T}}$, and Erwinia amylovora LMG $2024^{\mathrm{T}}$, expressed as percentages of the total fatty acids

\begin{tabular}{|c|c|c|c|c|c|c|}
\hline \multirow[b]{2}{*}{ Fatty acid } & \multicolumn{6}{|c|}{$\%$ in: } \\
\hline & $\begin{array}{l}\text { Pantoea ananas } \\
\quad(18 \text { strains })\end{array}$ & $\begin{array}{l}\text { Pantoea stewartii } \\
\text { subsp. stewartii } \\
\text { (8 strains) }\end{array}$ & $\begin{array}{l}\text { Pantoea stewartii } \\
\text { subsp. } \\
\text { indologenes } \\
\text { (10 strains) }\end{array}$ & $\begin{array}{l}\text { Pantoea agglomerans } \\
\text { LMG } 1286^{\mathrm{T}}\end{array}$ & $\begin{array}{l}\text { Pantoea dispersa } \\
\text { LMG } 2603^{\mathrm{T}}\end{array}$ & $\begin{array}{l}\text { Erwinia amylovora } \\
\text { LMG } 2024^{\mathrm{T}}\end{array}$ \\
\hline $10: 03 \mathrm{OH}$ & & & $<1(2)^{a}$ & & & \\
\hline $12: 0$ & $3.3-4.6$ & $3.4-4.8$ & $3.9-5.0$ & 3.8 & 4.2 & 5.1 \\
\hline $12: 03 \mathrm{OH}$ & $<1(13)$ & & $<1(1)$ & & & \\
\hline $13: 0$ & $<1(6)$ & & & & & \\
\hline $14: 0$ & $1.2-5.8$ & $0-5.1(6)$ & $1.3-2.8$ & 6.0 & 3.0 & 4.9 \\
\hline $14: 02 \mathrm{OH}$ & $0-3.3(17)$ & & $2.2-3.0$ & & 2.1 & \\
\hline $15: 0$ & $0-5.1(16)$ & & $<1(8)$ & 1.1 & $<1$ & $<1$ \\
\hline $15: 03 \mathrm{OH}$ & $<1(1)$ & & & & & \\
\hline $16: 0$ & $26.9-34.1$ & $24.3-29.6$ & 29.3-32.1 & 27.1 & 30.8 & 34.0 \\
\hline $16: 1$ cis 9 & $17.2-26.7$ & $11.9-15.4$ & $18.7-22.9$ & 24.2 & 10.6 & 24.5 \\
\hline $17: 0$ & $0-4.6(17)$ & $<1(1)$ & $0.5-1.1$ & $<1$ & $<1$ & 1.5 \\
\hline $17: 0 \mathrm{cyclo}^{b}$ & $2.2-11.2$ & & $1.4-3.5$ & 13.2 & 11.3 & 9.6 \\
\hline $17: 1^{b}$ & $<1(5)$ & & & & & \\
\hline 18:0 & $<1(17)$ & $1.5-2.4$ & $<1$ & & $<1$ & \\
\hline $18: 1$ iso $^{b}$ & $0-1.7(12)$ & $0-1.0(3)$ & $0.5-3.3$ & & & \\
\hline 19:0 cyclo C11-12 & $<1(9)$ & & & & 1.7 & \\
\hline $20: 1$ trans 11 & & $<1(6)$ & & & & \\
\hline Summed feature $2^{c}$ & $<1(9)$ & & & & & \\
\hline Summed feature $3^{d}$ & $7.5-10.6$ & $8.6-14.6$ & $7.8-11.2$ & 11.2 & 9.0 & 9.1 \\
\hline Summed feature $7^{e}$ & $14.2-19.9$ & $35.7-41.4$ & $21.8-25.4$ & 11.6 & 24.4 & 9.8 \\
\hline Unknown $13.961^{f}$ & $<1(14)$ & & $<1$ & & $<1$ & \\
\hline Unknown $14.503^{f}$ & $0-1.4(10)$ & $<1(6)$ & $<1$ & 1.0 & $<1$ & $<1$ \\
\hline Unknown $15.549^{f}$ & $<1(3)$ & & $<1(2)$ & & & \\
\hline
\end{tabular}

${ }^{a}$ If a fatty acid was not detected in all strains of a taxon, the number of strains in which it was detected is given in parentheses.

$b$ The position of the double bond or cyclopropane ring is unknown.

${ }^{c}$ Fatty acids 15:1 iso (position of double bond unknown) and 13:0 $3 \mathrm{OH}$ cannot be separated by using gas chromatography and the MIS system and are designated summed feature 2 .

${ }^{d}$ Fatty acids 16:1 iso (position of double bond unknown) and 14:0 $3 \mathrm{OH}$ cannot be separated by using gas chromatography and the MIS system and are designated summed feature 3 .

${ }^{e}$ Fatty acids 18:1 trans 6, 18:1 trans 9 , and 18:1 cis 11 cannot be separated by using gas chromatography and the MIS system and are designated summed feature 7 .

${ }^{f}$ Designations are the equivalent chain lengths relative to the lengths of known, straight-chain fatty acids.

Brenner et al. and our DNA hybridization group 2665 are the same.

From the high level of genotypic relatedness (79\% DNA binding) between the type strains of Erwinia ananas and Erwinia uredovora, it follows that these species names are subjective synonyms. Erwinia ananas Serrano 1928 is a senior synonym of Erwinia uredovora (Pon et al. 1954) Dye 1963 and therefore should be given nomenclatural priority. The contention that these names are synonyms is supported by the results of numerical analyses $(14,34,45)$, in which the type strains, as well as other strains, consistently were placed in the same phena, and by the similarity of the fatty acid compositions (Fig. 4) (2). Enwinia ananas has been identified as a cause of rot of pineapple, but no supplementary evidence that Erwinia ananas is the causative agent of the disease has been presented since the original report of Serrano (40). Erwinia uredovora was described as a Puccinia graminis pathogen (38). Although the two nomenspecies belonged to different protein electrophoretic profile groups, they each intermingled with strains that were from other ecological origins, including clinical origins, and were received as Erwinia herbicola or Enterobacter agglomerans. There seem to be no phenotypic features by which these organisms can be differentiated from each other $(34,45)$, and no subgrouping can be recognized from the DNA-DNA hybridization or fatty acid data. Thus, there is hardly any taxonomic or phytopathological support for the proposal of

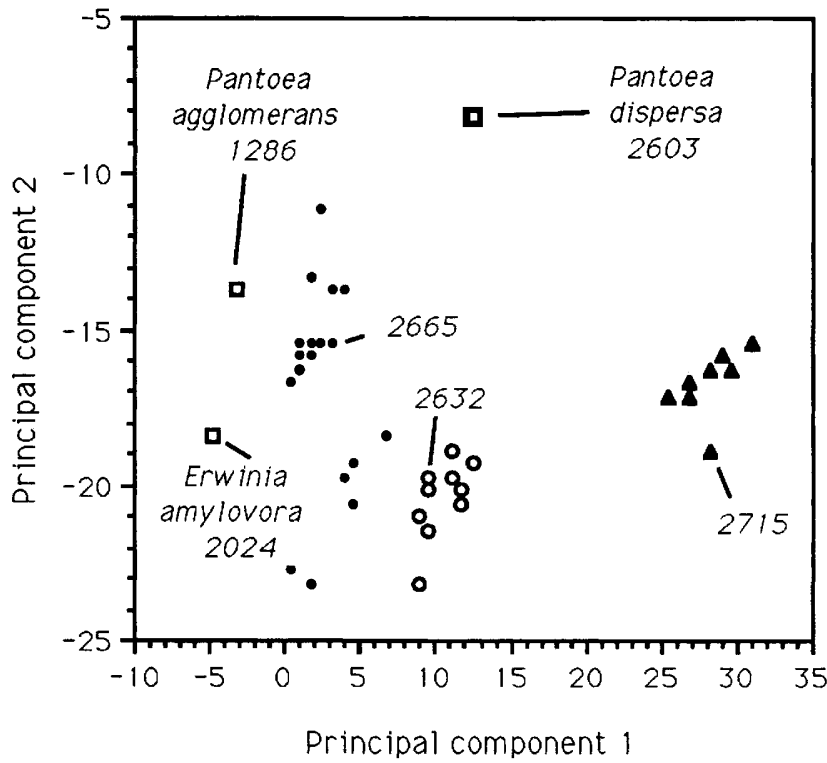

FIG. 4. Principal-component analysis of fatty acid compositions of 38 Pantoea strains and Erwinia amylovora LMG $2024^{\mathrm{T}}$, performed by using principal component 1 and principal component 2 . Symbols: - Pantoea ananas; O, Pantoea stewartii subsp. indologenes; $\Delta$, Pantoea stewartii subsp. stewartii; $\square$, other strains. The positions of the type strains are indicated. 
TABLE 4. Differential characteristics of Pantoea species

\begin{tabular}{|c|c|c|c|c|c|c|c|c|}
\hline Characteristic & $\begin{array}{c}\text { Pantoea } \\
\text { ananas }\end{array}$ & $\begin{array}{c}\text { Pantoea } \\
\text { stewartii } \\
\text { subsp. } \\
\text { stewartii }\end{array}$ & $\begin{array}{c}\text { Pantoea } \\
\text { stewartii } \\
\text { subsp. } \\
\text { indologenes }\end{array}$ & $\begin{array}{c}\text { Pantoea } \\
\text { agglomerans }\end{array}$ & $\begin{array}{l}\text { Pantoea } \\
\text { dispersa }\end{array}$ & $\begin{array}{c}\text { Pantoea } \\
\text { citrea }\end{array}$ & $\begin{array}{l}\text { Pantoea } \\
\text { punctata }\end{array}$ & $\begin{array}{c}\text { Pantoea } \\
\text { terrea }\end{array}$ \\
\hline \multicolumn{9}{|l|}{ API $20 \mathrm{E}$ tests } \\
\hline Nitrate reduced to nitrite & $\mathrm{d}^{a}$ & - & - & + & - & + & + & + \\
\hline Indole production & + & - & + & - & - & - & - & - \\
\hline Citrate utilization & + & - & + & d & + & + & + & + \\
\hline$\beta$-Galactosidase & + & + & + & + & + & + & - & - \\
\hline \multicolumn{9}{|l|}{ API 50CHE tests } \\
\hline Acid produced from glycerol & + & - & {$[+]$} & {$[-]$} & d & + & + & + \\
\hline Acid produced from $D$-arabitol & + & - & + & d & + & {$[+]$} & - & - \\
\hline Acid produced from sorbitol & {$[+]$} & - & - & - & - & {$[-]$} & - & {$[-]$} \\
\hline Acid produced from cellobiose & + & - & + & $\mathrm{d}$ & + & - & - & - \\
\hline Acid produced from maltose & + & - & + & + & + & + & {$[-]$} & {$[-]$} \\
\hline Acid produced from lactose & + & - & + & {$[-]$} & {$[-]$} & + & - & - \\
\hline Acid produced from $\alpha$-methyl-D-mannoside & {$[+]$} & - & - & - & - & - & - & - \\
\hline Acid produced from arbutin & + & - & + & + & - & {$[-]$} & - & + \\
\hline Acid produced from salicin & + & - & + & + & {$[-]$} & {$[-]$} & - & + \\
\hline Acid produced from raffinose & {$[+]$} & + & + & - & - & - & $\mathrm{d}$ & $\mathrm{d}$ \\
\hline Acid produced from D-turanose & - & - & - & - & + & - & - & - \\
\hline Acid produced from D-fucose & - & - & - & - & - & + & + & + \\
\hline Hydrolysis of esculin & $\mathrm{d}$ & - & + & + & + & - & {$[-]$} & + \\
\hline \multicolumn{9}{|l|}{ Other tests } \\
\hline Motility & + & - & {$[+]$} & + & + & - & - & + \\
\hline Malonate utilization & - & - & - & + & - & - & - & - \\
\hline Phenylalanine deaminase & - & - & - & + & - & - & - & - \\
\hline Growth on cis-aconitate & + & - & + & + & + & NT & NT & NT \\
\hline
\end{tabular}

${ }^{a}+$, at least $90 \%$ of the strains are positive; - , at least $90 \%$ of the strains are negative; [ + ], 76 to $89 \%$ of the strains are positive; [ $-1,11$ to $25 \%$ of the strains are positive; $d, 26$ to $75 \%$ of the strains are positive; NT, not tested. Data were obtained after $24 \mathrm{~h}$ (API 20E tests, motility), $48 \mathrm{~h}$ (API $50 \mathrm{CHE}$ tests), or 3 days (other tests) of incubation at $30^{\circ} \mathrm{C}$. Data for Pantoea citrea, Pantoea punctata, and Pantoea terrea are from reference 27.

Young et al. (47) that these species should be classified as separate pathovars of the same species.

Six strains constituted a second DNA hybridization group, as they exhibited 60 to $100 \%$ DNA binding to each other. Within this DNA hybridization group two subgroups were recognized (Fig. 3). DNA hybridization subgroup 2715 (93 to 99\% DNA binding) contained three Erwinia stewartii strains (including type strain LMG 2715), which were members of protein profile group IX (Fig. 2). The genotypic, electrophoretic, and fatty acid homogeneity (Table 3 and Fig. 4) of Erwinia stewartii confirms the phenotypic data (Table 2) (14, $34,45)$. The other DNA hybridization subgroup, DNA hybridization subgroup 2632 (94 to $100 \%$ DNA binding), included strains which were received as Erwinia herbicola or Erwinia ananas and were members of protein profile groups VI to VIII (Fig. 2 and 3). Strain LMG 2630 of DNA hybridization subgroup 2632 exhibited $60 \%$ DNA binding to subgroup 2715 (Erwinia stewartii) strains, and the other two subgroup 2632 strains exhibited 71 to $83 \%$ DNA binding to subgroup 2715 (Erwinia stewartii) strains. In the delineation of the bacterial species, $70 \%$ DNA binding was recommended as the minimum level of genotypic relatedness within a species, with a difference between the melting point of the homologous hybrid and the melting point of the heterologous hybrid of $5^{\circ} \mathrm{C}$ or less (46). Taking into account that our hybridization experiments were carried out at a restrictive temperature $\left(74^{\circ} \mathrm{C}\right)$, at which only fragments with high levels of sequential homology are allowed to reassociate (22), it follows that DNA hybridization subgroup 2715 (Erwinia stewartii) and DNA hybridization subgroup 2632 should be united in a single species. On the other hand, subgroup 2632 is phenotypically similar to DNA hybridization group 2665 (Tables 2 and 3) (45). It has been recom- mended that phenotypic characteristics should be allowed to override the phylogenetic concept of species only in a few exceptional cases and that a distinct genospecies that cannot be differentiated from another genospecies on the basis of any known phenotypic property should not be named (46). However, subgroup 2632 can be differentiated from group 2665 by its electrophoretic protein patterns (Fig. 1 and 2), by its overall fatty acid profile (Fig. 4), by a higher straightchain octodecenoic acid $\left(C_{18: 1}\right)$ (Table 3 , summed feature 7 ) content in its total cellular acid profile, and by its inability to produce acid from sorbitol and $\alpha$-methyl-D-mannoside. In the numerical analysis of Verdonck et al. (45), the two groups were separated into phena 12 and 13, which had a small overlap (two strains).

The considerable differences between subgroups 2632 and 2715 in biochemical characteristics (Tables 2 and 4), fatty acid composition (Table 3 and Fig. 4), and possibly also phytopathological features warrant the classification of these taxa as two subspecies within the same species. There are other examples, although they are not as extreme, of biochemically active and inactive sets of strains that are genotypically highly related and classified in the same species (e.g., the subspecies of Klebsiella pneumoniae [36]). In numerical analyses of the phenotypic features of Erwinia strains $(14,34,45)$, Enwinia stewartii consistently grouped near other biochemically less active Erwinia species, such as Erwinia amylovora, Erwinia mallotivora, and Erwinia rubrifaciens. It is not impossible that during the course of adaptation and specialization of Erwinia stewartii to its parasitic way of life on Zea mays and in its vector, the corn flea beetle, the ability to carry out some biochemical activities which had become superfluous for its survival was lost.

The generic position of Erwinia ananas (synonym, Er- 
winia uredovora) and Erwinia stewartii was questioned by Beji et al. (5) and Gavini et al. (19). These authors found that Pantoea agglomerans and Pantoea dispersa exhibited levels of DNA binding to the type strains of Erwinia ananas (56 and $39 \%$ ), Erwinia uredovora (51 and 47\%), and Erwinia stewartii (46 and $51 \%$ ) that were as high as the levels of DNA binding to each other and exhibited less than $28 \%$ DNA binding to Erwinia amylovora and Erwinia carotovora. Lind and Ursing (29) observed 53,48, and 41\% DNA binding between a representative strain of Pantoea agglomerans (see reference 19) and the type strains of Erwinia ananas, Erwinia uredovora, and Erwinia stewartii, respectively. Brenner et al. (7) found that their DNA hybridization group VI (corresponding to our DNA hybridization group 2665) exhibited 43 to $48 \%$ DNA binding to DNA hybridization groups XIII (Pantoea agglomerans [19]) and III (Pantoea dispersa [19]) and less than 23\% DNA binding to Erwinia amylovora and Erwinia carotovora. Kageyama et al. (27) used the $\mathrm{S} 1$ endonuclease method at $60^{\circ} \mathrm{C}$, which gives binding ratios that are at least $10 \%$ lower than those obtained by the hydroxyapatite method $\left(\right.$ at $60^{\circ} \mathrm{C}$ ) between strains that are related at less than species level (23). In their hybridization experiments with labeled DNAs from the type strains of Pantoea agglomerans and Pantoea dispersa, the type strains of Erwinia ananas, Erwinia uredovora, and Erwinia stewartii exhibited higher levels of DNA binding (30 to $40 \%$ ) than strains of Pantoea citrea, Pantoea punctata, and Pantoea terrea did (16 to $25 \%$ ) (27). In our experiments, in which a more restrictive incubation temperature $\left(74^{\circ} \mathrm{C}\right)$ was used, DNA hybridization group 2665 exhibited 30 to $32 \%$ DNA binding to Erwinia stewartii LMG $2175^{\mathrm{T}}$ and 32 to $39 \%$ DNA binding to DNA hybridization subgroup 2632 strains (Fig. 3). Strains belonging to these groups and subgroups exhibited 18 to $34 \%$ DNA binding to Pantoea agglomerans and Pantoea dispersa strains (Fig. 3). In the phenotypic analyses of Dye (14), Mergaert et al. (34), and Verdonck et al. (45) DNA hybridization group 2665 and subgroup 2632 strains, as well as strains now classified as Pantoea agglomerans and Pantoea dispersa, exhibited more phenotypic similarities to each other and to Erwinia cypripedii than to other Erwinia species. Erwinia stewartii grouped together with some species of the "amylovora group" sensu Dye (12). The apparent phenotypic homogeneity of the latter group, which included the species Erwinia amylovora, Erwinia mallotivora, Erwinia salicis, Erwinia rubrifaciens, Erwinia nigrifluens, Erwinia tracheiphila, and Erwinia quercina, is not reflected genotypically $(4,8,35)$ and is probably due to the occurrence of many negative, but not redundant, features in the numerical analyses.

We propose that DNA hybridization group 2665 should be classified in the genus Pantoea as Pantoea ananas (Serrano 1928) comb. nov. [synonyms, Erwinia ananas Serrano 1928, Erwinia uredovora (Pon et al. 1954) Dye 1963], which includes DNA hybridization group VI of Brenner et al. (7), and that DNA hybridization subgroup 2715 and subgroup 2632 should be united in one species, Pantoea stewartil (Smith 1898) comb. nov., with two subspecies, Pantoea stewartii subsp. stewartii (Smith 1898) comb. nov. (synonym, Erwinia stewartii) (for DNA hybridization subgroup 2715) and Pantoea stewartii subsp. indologenes subsp. nov. (for DNA hybridization subgroup 2632).

Description of Pantoea ananas (Serrano 1928) comb. nov. Pantoea ananas (Enwinia ananas Serrano 1928) (a'na.nas. M. L. n. Ananas, generic name of the pineapple). The description below is based on the data obtained for the 18 strains listed in Table 1 . Most strains grow at $4^{\circ} \mathrm{C}$, some strains grow at $37^{\circ} \mathrm{C}$, a few strains grow at $41^{\circ} \mathrm{C}$, but no strain grows at $44^{\circ} \mathrm{C}$. Indole is produced, and citrate is utilized. $\beta$-Galactosidase positive; ornithine decarboxylase, arginine dihydrolase, and phenylalanine deaminase negative. Most strains grow on L-aspartate, cis-aconitate, meso-tartrate, and D-malate, but not on acetate and DL-3-hydroxybutyrate. Acid is produced from L-arabinose, sucrose, cellobiose, D-arabitol, and D-mannitol and generally also from D-mannose, lactose, arbutin, and glycerol, but not from D-lyxose, L-sorbose, D-tagatose, D-fucose, melezitose, inulin, starch, glycogen, $\beta$-methyl-D-xyloside, meso-erythritol, or L-arabitol or on Jordan's tartrate medium. The biochemical and nutritional characteristics at $30^{\circ} \mathrm{C}$ are shown in Tables 2 and 4 through 6 , and the cellular fatty acid composition is shown in Table 3. The main fatty acids are (in order of decreasing relative content) hexadecanoic acid $\left(\mathrm{C}_{16: 0}\right)$, cis-9-hexadecenoic acid $\left(\mathrm{C}_{16: 1}\right.$ cis 9$)$, and straight-chain octadecenoic acids $\left(\mathrm{C}_{18: 1}\right)$. The $\mathrm{G}+\mathrm{C}$ contents of the DNAs of 10 strains range from 53.1 to $55.2 \mathrm{~mol} \%(9,17,24,43$; this study). Some strains (synonym, Erwinia ananas) are thought (40) to cause rot of Ananas comosus fruitlets, although this is doubted (13, 21). Other strains (synonym, Erwinia uredovora) attack the uredia of the wheat pathogen Puccinia graminis (38). Some strains have been isolated from seeds of Oryza sativa and Musa sp. or are of clinical origin. The type strain is strain LMG 2665 (= NCPPB 1846 = ATCC 33244 = PDDCC 1850 = ICPB EA175); its characteristics are shown in Table 2, and the $\mathrm{G}+\mathrm{C}$ content of its DNA is $55.0 \mathrm{~mol} \%$.

Description of Pantoea stewartii (Smith 1898) comb. nov. Pantoea stewartii [Erwinia stewartii (Smith 1898) Dye 1963] (stew.art'i.i. M. L. gen. n. stewartii, of Stewart; named after F. C. Stewart). The description below is based on the data obtained for the 18 strains listed in Table 1 . The species is divided into two subspecies; the common characteristics are shown in Tables 2 and 4 through 6 . $\beta$-Galactosidase positive; arginine dihydrolase, ornithine decarboxylase, phenylalanine deaminase, urease, and tetrathionate reductase negative. Tween 40 is hydrolyzed, but Tween 80 is not hydrolyzed. Growth occurs on L-aspartate and D-malate, but not on acetate or DL-3-hydroxybutyrate. Gelatin is not liquefied. Nitrate is not reduced to nitrite. Malonate is not utilized. Acid is produced from L-arabinose, sucrose, and D-mannitol, but not from L-lyxose, L-sorbose, D-tagatose, D-fucose, melezitose, $\alpha$-methyl-D-mannoside, sorbitol, inulin, starch, glycogen, $\beta$-methyl-D-xyloside, meso-erythritol, adonitol, meso-xylitol, or L-arabitol or on Jordan's tartrate medium. Isolated from $Z$. mays, several other grasses, $A$. comosus, and beetles. The $\mathrm{G}+\mathrm{C}$ contents of the DNAs of five strains range from 53.6 to $56.4 \mathrm{~mol} \%$ (43; this study). The type strain is strain LMG 2715 (= NCPPB $2295=$ ATCC 8199 = ICMP $257=$ DSM $30176=$ ICPB SS11 = IMET 11187); its characteristics are shown in Table 2 , and the $\mathrm{G}+\mathrm{C}$ content of its DNA is $55.1 \mathrm{~mol} \%$ (43).

Description of Pantoea stewartii subsp. stewartii (Smith 1898) comb. nov. The subspecies has all of the characteristics of the species. The description below is based on the data obtained for the eight strains listed in Table 1. A few strains grow at $4^{\circ} \mathrm{C}$, some strains grow at $37^{\circ} \mathrm{C}$, and no strain grows at $41^{\circ} \mathrm{C}$. The biochemical and nutritional characteristics at $30^{\circ} \mathrm{C}$ and characteristics that distinguish this subspecies from Pantoea stewartii subsp. indologenes are shown in Tables 2 and 4. Nonmotile. No indole is produced. Esculin is not hydrolyzed. Citrate and mucate are not utilized. No growth occurs on cis-aconitate and DL-4-aminobutyrate. No acid is produced from L-rhamnose, cellobiose, maltose, lactose, gentiobiose, $\alpha$-methyl-D-glucoside, arbutin, salicin, amygda- 


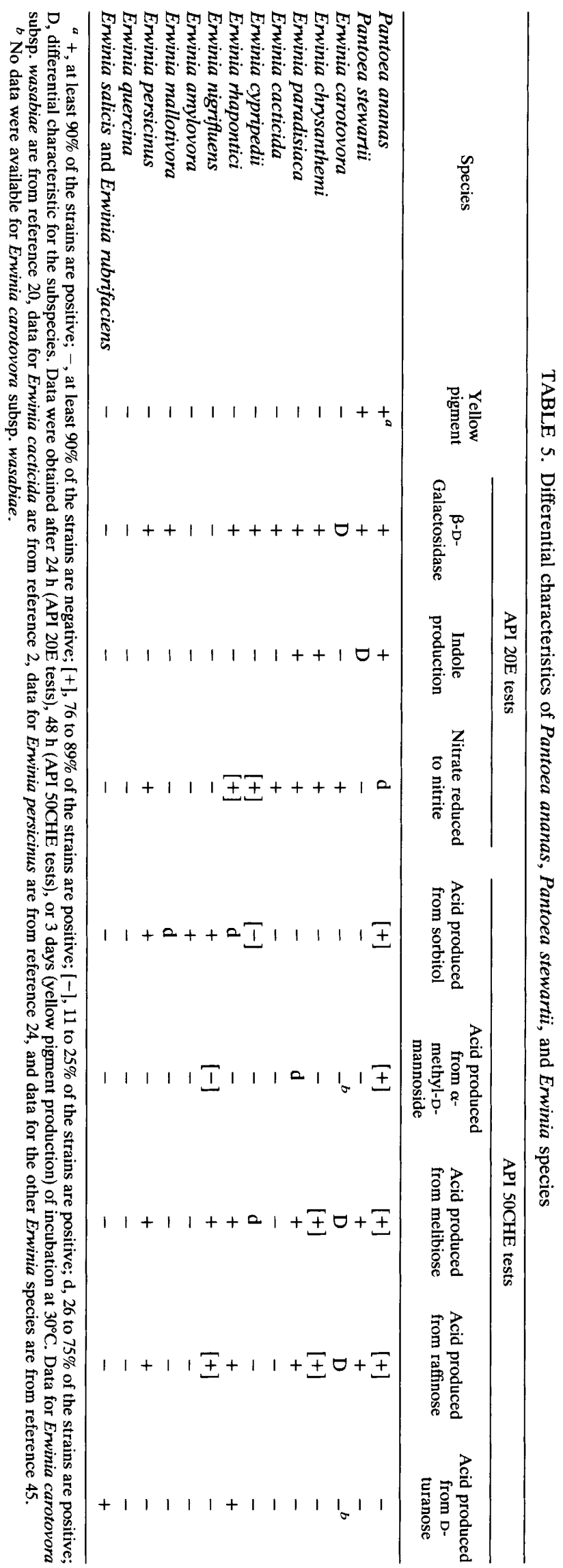

lin, glycerol, D-arabitol, dulcitol, meso-inositol, D-gluconate, 2-keto-D-gluconate, or 5-keto-D-gluconate. The cellular fatty acid composition is shown in Table 3 . The main fatty acids are (in order of decreasing relative content) straight-chain octadecenoic acids $\left(\mathrm{C}_{18: 1}\right)$, hexadecanoic acid $\left(\mathrm{C}_{16: 0}\right)$, and cis-9-hexadecenoic acid $\left(\mathrm{C}_{16: 1 \text { cis }}\right.$ 9). The $\mathrm{G}+\mathrm{C}$ contents of the DNAs of two strains are 54.6 and $55.1 \mathrm{~mol} \%$ (43). Strains of Pantoea stewartii subsp. stewartii (synonym, Enwinia stewartii) are the causative agents of Stewart's bacterial wilt of corn, a vascular disease of $Z$. mays, and exist in the insect vector, the corn flea beetle Chaetocnema pulicaria (1). The type strain is the same as the type strain of the species.

Description of Pantoea stewartii subsp. indologenes subsp. nov. Pantoea stewartii subsp. indologenes (in.do.lo'gen.es. M. L. n. indolum, indole; Gr. n. gennao, to produce; M. L. adj. indologenes, indole producing). The subspecies has all of the characteristics of the species. The description below is based on the data obtained for the 10 strains listed in Table 1. Many strains grow at 4 and $37^{\circ} \mathrm{C}$ and some strains grow at $41^{\circ} \mathrm{C}$, but few strains grow at $44^{\circ} \mathrm{C}$. The biochemical and nutritional characteristics at $30^{\circ} \mathrm{C}$ and characteristics that distinguish this subspecies from Pantoea stewartii subsp. stewartii are shown in Tables 2 and 4. Indole is produced. Esculin is hydrolyzed. Growth occurs on cis-aconitate and meso-tartrate. Acid is produced from cellobiose, maltose, lactose, arbutin, salicin, and D-arabitol. The cellular fatty acid composition is shown in Table 3 . The main fatty acids are (in order of decreasing relative content) hexadecanoic acid $\left(\mathrm{C}_{16: 0}\right)$, straight-chain octadecenoic acids $\left(\mathrm{C}_{18: 1}\right)$, and cis-9-hexadecenoic acid $\left(\mathrm{C}_{16: 1 \text { cis } 9}\right)$. The $\mathrm{G}+\mathrm{C}$ contents of the DNAs of three strains are $53.6 \mathrm{~mol} \%$ (43), $54.5 \mathrm{~mol} \%$, and $56.4 \mathrm{~mol} \%$ (this study). Strains of Pantoea stewartii subsp. indologenes are thought to cause leaf spot on foxtail millet (Setaria italica) and pearl millet (Pennisetum americanum) and rot of $A$. comosus; one strain was isolated from cluster bean (Cyamopsis tetragonolobus). The type strain is strain LMG 2632 (= NCPPB $2280=$ ICMP 77); its characteristics are shown in Table 2, and the $\mathrm{G}+\mathrm{C}$ content of its DNA is $56.4 \mathrm{~mol} \%$.

Emended description of the genus Pantoea Gavini, Mergaert, Beji, Mielcarek, Izard, Kersters, and De Ley 1989. Pantoea (Pan.toe'a. Gr. adj. pantoios, of all sorts and sources; M.L. fem. n. Pantoea, [bacteria] from diverse [geographical and ecological] sources). The description below is based on the data of Beji et al. (5), Gavini et al. (19), and Kageyama et al. (27) and the data in this paper. Gram-negative, noncapsulated, nonsporeforming, straight rods that are 0.5 to 1.3 by 1.0 to $3.0 \mu \mathrm{m}$. Cells are motile and peritrichous or are nonmotile. Cultures grow well on nutrient agar at $30^{\circ} \mathrm{C}$. Colonies on nutrient agar are smooth, translucent, and more or less convex with entire margins. Colonies are yellow, pale beige to pale reddish yellow, or nonpigmented. Facultatively anaerobic and oxidase negative. No gas is produced from D-glucose. No lysine decarboxylase, tryptophan deaminase, or urease activity. Pectate is not degraded, and hydrogen sulfide is not produced from thiosulfate. Acid is produced from D-xylose, D-ribose, D-galactose, D-fructose, trehalose, and $N$-acetyl-D-glucosamine, but not from D-arabinose, L-xylose, L-fucose, or D-turanose. Isolated from plants, seeds, fruits, soils, and water, as well as from humans (wounds, blood, urine, internal organs) and animals, in several parts of the world. Some strains are (or have been thought to be) phytopathogenic. The $\mathrm{G}+\mathrm{C}$ contents of the DNAs range from 49.7 to $60.6 \mathrm{~mol} \%(9,17,19$, $25,27,43$; this study). The type species is Pantoea agglom- 
TABLE 6. Differential characteristics of Pantoea ananas, Pantoea stewartii, and other members of the family Enterobacteriaceae ${ }^{a}$

\begin{tabular}{|c|c|c|c|c|c|c|c|c|c|c|}
\hline Species & $\begin{array}{l}\text { Yellow } \\
\text { pigment }\end{array}$ & $\begin{array}{l}\text { Indole } \\
\text { produc- } \\
\text { tion }\end{array}$ & $\begin{array}{l}\text { Nitrate } \\
\text { reduced } \\
\text { to nitrite }\end{array}$ & $\begin{array}{c}\text { Esculin } \\
\text { hydrolysis }\end{array}$ & $\begin{array}{l}\text { Gas produced } \\
\text { from D- } \\
\text { glucose }\end{array}$ & $\begin{array}{l}\text { Ornithine } \\
\text { decarboxy- } \\
\text { lase }\end{array}$ & $\begin{array}{l}\text { Malonate } \\
\text { utilization }\end{array}$ & $\begin{array}{c}\text { Mucate } \\
\text { utilization }\end{array}$ & $\begin{array}{c}\text { Acid } \\
\text { produced } \\
\text { from sorbitol }\end{array}$ & $\begin{array}{l}\text { Acid produced } \\
\text { from D-arabitol }\end{array}$ \\
\hline Pantoea ananas & $t^{b}$ & + & $\mathrm{d}$ & $\mathrm{d}$ & - & - & - & - & {$[+]$} & + \\
\hline Pantoea stewartii & + & D & - & - & - & - & - & - & -1 & $\mathrm{D}$ \\
\hline Escherichia adecarboxylata & + & + & + & + & + & - & d & + & - & + \\
\hline Escherichia coli & - & + & + & d & + & d & - & + & + & - \\
\hline Enterobacter cloacae & - & - & + & d & + & + & {$[+]$} & {$[+]$} & + & {$[-]$} \\
\hline Enterobacter sakazakii & + & {$[-]$} & + & + & + & + & {$[-]$} & - & - & - \\
\hline Citrobacter diversus & - & + & + & - & + & + & + & + & + & + \\
\hline Serratia plymuthica & - & - & + & + & - & - & - & - & d & - \\
\hline Klebsiella oxytoca & - & + & + & + & + & - & + & + & + & + \\
\hline Rahnella aquatilis & - & - & + & + & {$[+]$} & - & + & $\mathrm{d}$ & + & - \\
\hline Ewingella americana & - & - & + & + & - & - & - & - & - & + \\
\hline Cedecea davisae & - & - & + & d & {$[+]$} & + & {$[+]$} & - & - & + \\
\hline
\end{tabular}

${ }^{a}$ Data from reference 6.

$b_{+}+$, at least $90 \%$ of the strains are positive; -, at least $90 \%$ of the strains are negative; [+], 76 to $89 \%$ of the strains are positive; [-], 11 to $25 \%$ of the strains are positive; d, 26 to $75 \%$ of the strains are positive; D, differential characteristic for the subspecies. Data were obtained after 24 to $72 \mathrm{~h}$ of incubation at $30^{\circ} \mathrm{C}$ (Pantoea species) or $36^{\circ} \mathrm{C}$ (other species).

erans (Beijerinck 1888) Gavini, Mergaert, Beji, Mielcarek, Izard, Kersters, and De Ley 1989.

The differential characteristics of Pantoea ananas, Pantoea stewartii subsp. stewartii, and Pantoea stewartii subsp. indologenes are shown in Tables 2 and 4. Pantoea stewartii subsp. stewartii and Pantoea stewartii subsp. indologenes can be further differentiated from Pantoea ananas by the higher percentages of straight-chain octodecenoic acids $\left(\mathrm{C}_{18: 1}\right)$ (Table 3 , summed in feature 7 ) in their fatty acid compositions. Unlike Pantoea stewartii subsp. indologenes, Pantoea stewartii subsp. stewartii lacks 2-hydroxytetradecanoic acid $\left(\mathrm{C}_{14: 0} 2 \mathrm{OH}\right)$ and cyclo-heptadecanoic acid $\left(\mathrm{C}_{17: 0}\right.$ cyclo). Characteristics useful for differentiation from other Pantoea species, Erwinia species, and other members of the Enterobacteriaceae are shown in Tables 4 through 6, respectively.

Data presented above or published previously $(5,19,34)$ demonstrate that the API $20 \mathrm{E}$ commercial kits are not sufficient for the identification of most Pantoea and Erwinia species. An updating of the APILAB identification program is needed, and several other tests, some of which are contained in the API 50CHE system, have to be used to differentiate Pantoea ananas, Pantoea stewartii subsp. stewartii, and Pantoea stewartii subsp. indologenes from each other and from other taxa (Tables 4 through 6). The use of the MIS data base for the identification of the fatty acid profiles seems promising; Pantoea ananas and Pantoea stewartii subsp. stewartii were correctly identified, while the newly proposed taxon Pantoea stewartii subsp. indologenes produced an unidentified, unique fatty acid profile.

Of the 13 DNA hybridization groups of Brenner et al. (7), 5 have been named; group III has been described as Pantoea dispersa (19), group VI has been described as Pantoea ananas (this paper), group XI has been described as Escherichia adecarboxylata (26), group XIII has been described as Pantoea agglomerans $(5,19)$, and group $\mathrm{V}$ has been provisionally classified as Pantoea sp. $(5,19)$. The taxonomic positions of DNA hybridization groups I, II, IV, VII to $X$, and XII of Brenner et al. (7) remain to be elucidated.

\section{ACKNOWLEDGMENTS}

J.M. and L.V. are indebted to the Instituut tot Aanmoediging van het Wetenschappelijk Onderzoek in Nijverheid en Landbouw (Bel- gium) for a scholarship. K.K. is indebted to the Fund for Medical Scientific Research (Belgium) for research and personnel grants.

\section{REFERENCES}

1. Agrios, G. N. 1978. Plant pathology, 2nd ed. Academic Press, New York.

2. Alcorn, S. M., T. V. Orum, A. G. Steigerwalt, J. M. Foster, J. C. Fogleman, and D. J. Brenner. 1991. Taxonomy and pathogenicity of Erwinia cacticida sp. nov. Int. J. Syst. Bacteriol. 41:197212.

3. Ayers, S. H., P. Rupp, and W. T. Johnson. 1919. A study of the alkali forming bacteria in milk. U. S. Department of Agriculture bulletin 782. U.S. Department of Agriculture, Washington, D.C.

4. Azad, H. R., and C. I. Kado. 1980. Numerical and DNA:DNA reassociation analyses of Erwinia rubrifaciens and other members of the Enterobacteriaceae. J. Gen. Microbiol. 120:117-129.

5. Beji, A., J. Mergaert, F. Gavini, D. Izard, K. Kersters, H. Leclerc, and J. De Ley. 1988. Subjective synonymy of Erwinia herbicola, Erwinia milletiae, and Enterobacter agglomerans and redefinition of the taxon by genotypic and phenotypic data. Int. J. Syst. Bacteriol. 38:77-88.

6. Brenner, D. J. 1984. Family I. Enterobacteriaceae Rahn 1937, p. 408-420. In N. R. Krieg and J. G. Holt (ed.), Bergey's manual of systematic bacteriology, vol. 1. The Williams \& Wilkins Co., Baltimore.

7. Brenner, D. J., G. R. Fanning, J. K. Leete Knutson, A. G. Steigerwalt, and M. I. Krichevsky. 1984. Attempts to classify herbicola group-Enterobacter agglomerans strains by deoxyribonucleic acid hybridization and phenotypic tests. Int. J. Syst. Bacteriol. 34:45-55.

8. Brenner, D. J., G. R. Fanning, and A. G. Steigerwalt. 1974. Deoxyribonucleic acid relatedness among erwineae and other Enterobacteriaceae: the gall, wilt, and dry-necrosis organisms (genus Erwinia Winslow et al., sensu stricto). Int. J. Syst. Bacteriol. 24:197-204.

9. De Ley, J. 1968. DNA base composition of yellow Enwinia strains. Antonie van Leeuwenhoek J. Microbiol. Serol. 34:257262.

10. De Ley, J. 1970. Reexamination of the association between melting point, buoyant density and chemical base composition of deoxyribonucleic acid. J. Bacteriol. 101:738-754.

11. De Ley, J., H. Cattoir, and A. Reynaerts. 1970. The quantitative measurement of DNA hybridization from renaturation rates. Eur. J. Biochem. 12:133-142.

12. Dye, D. W. 1968. A taxonomic study of the genus Erwinia. I. The 'amylovora' group. N. Z. J. Sci. 11:590-607.

13. Dye, D. W. 1969. A taxonomic study of the genus Erwinia. III. The 'herbicola' group. N. Z. J. Sci. 12:223-236.

14. Dye, D. W. 1981. A numerical taxonomic study of the genus 
Erwinia. N. Z. J. Agric. Res. 24:223-231.

15. Ewing, W. H., and B. R. Davis. 1970. Media and tests for differentiation of Enterobacteriaceae. Public Health Service, U. S. Department of Health, Education, and Welfare, Washington, D.C.

16. Ewing, W. H., and M. A. Fife. 1972. Enterobacter agglomerans (Beijerinck) comb. nov. (the herbicola-lathyri bacteria). Int. J. Syst. Bacteriol. 22:4-11.

17. Gardner, J. M., and C. I. Kado. 1972. Comparative base sequence homologies of the deoxyribonucleic acids of Erwinia species and other Enterobacteriaceae. Int. J. Syst. Bacteriol. 22:201-209.

18. Gavini, F., B. Lefebvre, and H. Leclerc. 1983. Etude taxonomique de souches appartenant ou apparentées au genre Erwinia groupe Herbicola et à l'espèce Enterobacter agglomerans. Syst. Appl. Microbiol. 4:218-235.

19. Gavini, F., J. Mergaert, A. Beji, C. Mielcarek, D. Izard, K. Kersters, and J. De Ley. 1989. Transfer of Enterobacter agglomerans (Beijerinck 1888) Ewing and Fife 1972 to Pantoea gen. nov. as Pantoea agglomerans comb. nov. and description of Pantoea dispersa sp. nov. Int. J. Syst. Bacteriol. 39:337-345.

20. Goto, M., and K. Matsumoto. 1987. Enwinia carotovora subsp. wasabiae subsp. nov. isolated from diseased rhizomes and fibrous roots of Japanese horseradish (Eutrema wasabi Maxim.). Int. J. Syst. Bacteriol. 37:130-135.

21. Graham, D. C., and W. Hodgkiss. 1967. Identity of Gramnegative, yellow pigmented, fermentative bacteria isolated from plants and animals. J. Appl. Bacteriol. 30:175-189.

22. Grimont, P. A. D., and M. Y. Popoff. 1980. Use of principal component analysis in interpretation of deoxyribonucleic acid relatedness. Curr. Microbiol. 4:337-342.

23. Grimont, P. A. D., M. Y. Popoff, F. Grimont, C. Coynault, and M. Lemelin. 1980. Reproducibility and correlation study of three deoxyribonucleic acid hybridization procedures. Curr. Microbiol. 4:325-330.

24. Hao, M. V., D. J. Brenner, A. G. Steigerwalt, Y. Kosako, and K. Komagata. 1990. Erwinia persicinus, a new species isolated from plants. Int. J. Syst. Bacteriol. 40:379-383.

25. Holländer, R. 1980 . Charakterisierung von Erwinia-Stämmen inbesondere der Herbicola-Gruppe durch Chinone der Atmungskette und Enzyme des Fumarat-Stoffwechsels. Zentralbl. Bakteriol. Parasitenkd. Infektionskr. Hyg. Abt. 1 Orig. Reihe C 1:243-256.

26. Izard, D., J. Mergaert, F. Gavini, A. Beji, K. Kersters, J. De Ley, and H. Leclerc. 1985. Separation of Escherichia adecarboxylata from the "Erwinia herbicola-Enterobacter agglomerans" complex and from the other Enterobacteriaceae by nucleic acid and protein electrophoretic techniques. Ann. Inst. Pasteur Microbiol. 136B:151-168.

27. Kageyama, B., M. Nakae, S. Yagi, and T. Sonoyama. 1992. Pantoea punctata sp. nov., Pantoea citrea sp. nov., and Pantoea terrea sp. nov. isolated from fruit and soil samples. Int. J. Syst. Bacteriol. 42:203-210.

28. Le Minor, L., M. Chippaux, F. Pichinoty, C. Coynault, and M. Piéchaud. 1970. Méthodes simples permettant de rechercher la tétrathionate réductase en cultures liquides ou sur colonies isolées. Ann. Inst. Pasteur 119:733-737.

29. Lind, E., and J. Ursing. 1986. Clinical strains of Enterobacter agglomerans (synonyms: Enwinia herbicola, Erwinia milletiae) identified by DNA-DNA hybridization. Acta Pathol. Microbiol. Immunol. Scand. Sect. B 94:205-213.

30. Marmur, J. 1961. A procedure for the isolation of deoxyribo- nucleic acid from microorganisms. J. Mol. Biol. 3:208-218.

31. Marmur, J., and P. Doty. 1962. Determination of the base composition of deoxyribonucleic acid from its thermal denaturation temperature. J. Mol. Biol. 5:109-118.

32. Mergaert, J. 1989. A taxonomic study of the "Enwinia herbicola-Enterobacter agglomerans complex." Acad. Analecta 51: $1-23$.

33. Mergaert, J., F. Gavini, K. Kersters, H. Leclerc, and J. De Ley. 1983. Phenotypic and protein electrophoretic similarities between strains of Enterobacter agglomerans, Erwinia herbicola, and Enwinia milletiae from clinical or plant origin. Curr. Microbiol. 8:327-331.

34. Mergaert, J., L. Verdonck, K. Kersters, J. Swings, J. M. Beufgras, and J. De Ley. 1984. Numerical taxonomy of Erwinia species using API systems. J. Gen. Microbiol. 130:1893-1910.

35. Murata, N., and M. P. Starr. 1974. Intrageneric clustering and divergence of Erwinia strains from plants and man in the light of deoxyribonucleic acid segmental homology. Can. J. Microbiol. 20:1545-1565.

36. Ørskov, I. 1984. Genus V. Klebsiella Trevisan $1885,105^{\mathrm{AL}}$, p. 461-465. In N. R. Krieg and J. G. Holt (ed.), Bergey's manual of systematic bacteriology, vol. 1. The Williams \& Wilkins Co., Baltimore.

37. Paton, A. M. 1959. An improved method for preparing pectate gels. Nature (London) 183:1812-1813.

38. Pon, D. S., C. E. Townsend, G. E. Wessman, C. G. Schmitt, and C. H. Kingsolver. 1954. A Xanthomonas parasitic on uredia of cereal rust. Phytopathology 44:707-710.

39. Richard, C. 1984. Genus VI. Enterobacter Hormaeche and Edwards $1960,72^{\text {AL }}$, p. 465-469. In N. R. Krieg and J. G. Holt (ed.), Bergey's manual of systematic bacteriology, vol. 1. The Williams \& Wilkins Co., Baltimore.

40. Serrano, F. B. 1928. Bacterial fruitlet brown-rot of pineapple in the Philippines. Philipp. J. Sci. 36:271-305.

41. Sierra, G. 1957. A simple method for the detection of lipolytic activity of microorganisms and some observations on the influence of contact between cells and fatty substances. Antonie van Leeuwenhoek 23:15-22.

42. Skerman, V. B. D., V. McGowan, and P. H. A. Sneath (ed.). 1980. Approved lists of bacterial names. Int. J. Syst. Bacteriol. 30:225-420.

43. Starr, M. P., and M. Mandel. 1969. DNA base composition and taxonomy of phytopathogenic and other enterobacteria. J. Gen. Microbiol. 56:113-123.

44. Tamura, K., R. Sakazaki, Y. Kosako, and E. Yoshizaki. 1986. Leclercia adecarboxylata gen. nov., comb. nov., formerly known as Escherichia adecarboxylata. Curr. Microbiol. 13:179184.

45. Verdonck, L., J. Mergaert, C. Rijckaert, J. Swings, K. Kersters, and J. De Ley. 1987. The genus Erwinia: a numerical analysis of phenotypic features. Int. J. Syst. Bacteriol. 37:4-18.

46. Wayne, L. G., D. J. Brenner, R. R. Colwell, P. A. D. Grimont, O. Kandler, M. I. Krichevsky, L. H. Moore, W. E. C. Moore, R. G. E. Murray, E. Stackebrandt, M. P. Starr, and H. G. Trüper. 1987. Report of the Ad Hoc Committee on Reconciliation of Approaches to Bacterial Systematics. Int. J. Syst. Bacteriol. 37:463-464.

47. Young, J. M., D. W. Dye, J. F. Bradbury, C. G. Panagopoulos, and C. F. Robbs. 1978. A proposed nomenclature and classification for plant pathogenic bacteria. N. Z. J. Agric. Res. 21:153-177. 